PONTIFÍCIA UNIVERSIDADE CATÓLICA DO RIO DE JANEIRO - PUCRIO

\title{
A DUPLA PATERNIDADE NO REGISTRO CIVIL
}

LUCIANA MONTEIRO HABIB 


\section{LUCIANA MONTEIRO HABIB}

\section{A DUPLA PATERNIDADE NO REGISTRO CIVIL}

Projeto de Trabalho de Conclusão de Curso apresentado na CCE Coordenação Central de Extensão como requisito básico para a conclusão do Curso de Pós Graduação e Especialização em Direito das Famílias e das Sucessões.

RIO DE JANEIRO

2018 


\section{A DUPLA PATERNIDADE NO REGISTRO CIVIL}

Por

\section{LUCIANA MONTEIRO HABIB}

Este estudo monográfico de pós-graduação em Direito das Famílias e Sucessões, foi apresentado no dia 19 de outubro de 2018, como requisito parcial para a obtenção do título de pós-graduanda em 2018, tendo sido aprovado pela Banca Examinadora composta pelos professores:

Prof. ${ }^{\text {a }}$ Caitlin Mulholland

Orientadora - PUC

Prof. ${ }^{\mathrm{a}}$ Thamis Dalsenter

Examinadora -PUC 
DEDICO este trabalho de conclusão aos meus pais, marido e filha, que muito me apoiaram. 


\section{AGRADECIMENTOS}

Primeiramente agradecer à Deus por me dar o privilégio de concluir mais uma etapa na minha vida, me dando saúde e suporte emocional pelas batalhas que enfrentei durante a realização deste curso.

Agradecer a esta Universidade e toda sua direção, bem como seus professores pela orientação e sabedoria transmitida aos seus alunos.

Ao meu pai Carlos Alberto (in memoriam) e Conceição pela minha vida e dedicação, principalmente ao meu pai que sempre acreditou em mim e me apontou o caminho certo a seguir.

Ao meu marido Jorge que sempre me apoiou para concluir esse curso e a minha filha Thaciane sem você nada teria acontecido.

Enfim, agradecer a todos que direta e indiretamente contribuíram para obtenção deste título. 
Que os vossos esforços desafiem as impossibilidades, lembrai-vos de que as grandes coisas do homem foram conquistadas do que parecia impossível."

Charles Chaplin 


\section{RESUMO}

HABIB, Luciana Monteiro. A Dupla Paternidade no Registro Civil. 2018. 36 fls. Monografia (Pós-Graduação em Direito Civil) PUC- Pontifícia Universidade Católica do Rio de Janeiro, Rio de Janeiro, 2018.

A presente monografia de conclusão de pós - graduação traz uma discussão acerca da A Dupla Paternidade no Registro Civil. Estabeleceu-se como problemática o seguinte: a dupla paternidade corresponde a uma nova situação fática cada vez mais frequente na sociedade e, como tal, impõe a adequação do direito diante das necessidades sociais. A metodologia fundamental utilizada foi a comparativa com os métodos qualitativos. Para o desenvolvimento das ideias apresentadas, foi utilizada a pesquisa bibliográfica, voltada para a análise de legislações e doutrinas pertinentes ao assunto ora enfocado e do recente Provimento editado pelo CNJ n.63/2017.

Palavras-chave: Dupla paternidade, sociafetivo, homoafetiva, Registro Civil, legislador. 


\section{ABSTRAT}

HABIB, Luciana Monteiro. The Dual Paternity in the Civil Registry. 2018. 36 fls. Monograph (Post-Graduation in Civil Law) PUC- Pontifical Catholic University of Rio de Janeiro, Rio de Janeiro, 2018.

This post - graduate monograph brings a discussion about Double Parenting in the Civil Registry. The following was problematic: double paternity corresponds to a new and more frequent factual situation in society and, as such, imposes the adjustment of the right to social needs. The fundamental methodology used was the comparative with the qualitative methods. For the development of the presented ideas, the bibliographical research was used, focused on the analysis of the legislations and doctrines pertinent to the subject focused here.

Key words: Double parenthood, social security, homoafetive, Civil Registry, legislator. 
INTRODUÇÃO .............................................................................10

1 A EVOLUÇÃO HISTÓRICA DA PATERNIDADE SOCIOAFETIVA...............12

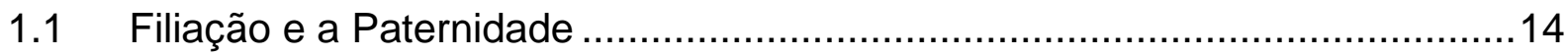

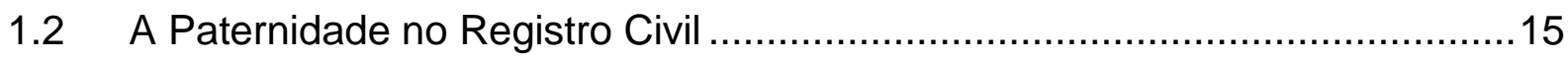

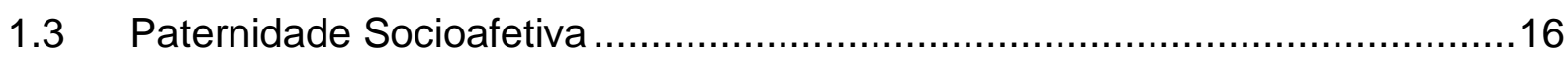

1.4 Paternidade Biologica ....................................................................... 18

1.5 Família e o seu desenvolvimento conforme o Código Civil de 1916 e as suas devidas implantações através do Código Civil de 2002 ...............................18

1.6 Família advinda da Constituição Federal de 1988 .....................................19

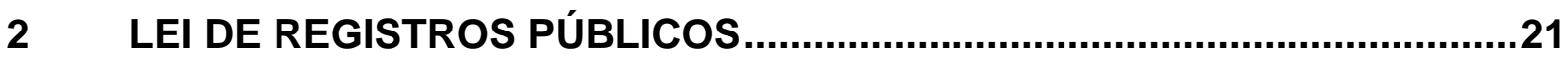

2.1 O Registro Civil e a Dupla Paternidade no Brasil...........................................22

3 A DUPLA PATERNIDADE ATRAVÉS DP RECURSO EXTRAORDINÁRIO №



3.1 O Direito e a Jurisprudência a Respeito da Dupla Paternidade......................27

3.2 Diversidades de Opiniões Advinda do Reconhecimento da Dupla Paternidade, Advinda do STF

4 É POSSÍVEL O RECONHECIMENTO DA FILIAÇÃO COM A DUPLA

PATERNIDADE

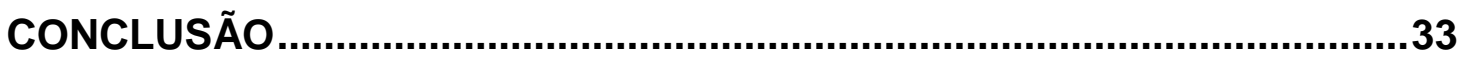

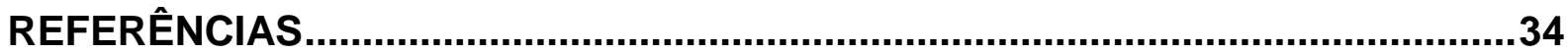




\section{INTRODUÇÃO}

O presente trabalho tem como objetivo abordar o assunto referente a inclusão de duas paternidades no registro civil podendo ser realizado por casais heterossexuais ou mesmo de famílias homossexuais na forma de adoção, de pai biológico ou por vínculo afetivo, sendo uma forma de multiparentalidade reconhecida hoje no nosso ordenamento jurídico.

Com a multiparentalidade o registro passa a conter dois pais biológicos ou mesmo socioafetivos, esse novo formato de Família seria uma solução para quem vive nessa situação fática, atendendo assim o melhor interesse da criança e do adolescente respeitando assim o vínculo de uma relação já existente nessas famílias.

A discussão acerca do tema tende a proporcionar os fundamentos teóricos para o ajustamento da legislação infraconstitucional aos Direitos fundamentais visto que esse novo modelo de família vem sendo reconhecido em decisões judiciais, inclusive perante ao STF possibilitando a inclusão de duas paternidades no registro civil e atualmente no provimento 63/2017 do Conselho Nacional de Justiça.

E como possibilitar a inclusão de duas paternidades sem impor sobrevalência sobre o vínculo biológico ou afetivo?

E quais seriam os efeitos desse reconhecimento? Como alimentos, guarda, sucessões e etc...

Tal tema tem como justificativa a grande relevância no nosso ordenamento jurídico , não se pode negar o reconhecimento dessa filiação pelo simples fato de os pais serem do mesmo sexo ou mesmo possuir um outro pai registral no registro civil, desta forma estaria infringindo o instituto da filiação e de todos os direitos inerentes ao ser humano, devendo sempre preservar o Princípio da Dignidade da Pessoa Humana que rege toda órbita do Direito de Família.

A escolha desse tema foi a recente decisão do STF da Relatoria do Ministro Luiz Fux que trouxe inovações no que tange o tema escolhido, assim este trabalho propõe-se a esclarecer estas mudanças para melhor compreensão do assunto abordado relevante no Direito de Família e Registral, questões estas relativas ao direito ao nome e a Dignidade essenciais a toda pessoa sendo salvaguardados pela nossa Constituição Federal. 
Tendo em vista que esse tema é recente e pouco discutido no nosso ordenamento jurídico, pretendo contribuir para debates que estão surgindo sobre a interpretação de novas decisões à respeito diante da decisão do STF e do Conselho Nacional de Justiça que editou o Provimento de no 63/2017 afim de agilizar e regulamentar no âmbito extrajudicial o reconhecimento voluntario da parentalidade socioafetivo podendo assim formar um novo conceito de família.

Contudo, adota como objetivo geral a analisar a possibilidade jurídica de duas ou mais paternidades no Registro, bem como os objetivos especificos, apresentar a evolução da família no ordenamento jurídico; Conceituar os tipos de família; Justificar a possibilidade jurídica de inclusão de mais de um pai no Registro Civil com fundamento no Princípio Constitucional da Dignidade de Pessoa Humana.

Dessa forma, vemos como marco teórico as decisões e jurisprudência que deram início a evolução do Direito de Família e que contribuíram para a modificação do novo modelo de Família contemporânea, esse paradigma trouxe também a necessidade de modificações legislativas, afim de se enquadrarem na nova realidade social, cultural e familiar. Entretanto para análise do tema faremos abordagens e conceitos de diferentes doutrinadores que pensam à respeito desse assunto e outros com pensamentos semelhantes que complementam a ideia de uma nova realidade jurídica ainda em construção no nosso ordenamento jurídico. Buscando uma metodologia de desenvolvimento pela abordagem teórica tendo como coleta de artigos acadêmicos publicados na internet, pesquisas bibliográficas, legislações e jurisprudências à respeito do tema. 


\section{A EVOLUÇÃO HISTÓRICA DA PATERNIDADE SOCIOAFETIVA}

Ao longo de anos, perpetuou-se que a família seria o alicerce de toda a sociedade, fundamentos e costumes que ainda são perpetuados atualmente, graça ao desenvolvimento social e educacional dos componentes familiares.

$\mathrm{Na}$ atualidade temos famílias formadas por casais homossexuais, amplamente aceitável no presente, o que era completamente proibido era tratado como crime e afronta a sociedade essa formação familiar. Dessa forma, a Paternidade, somente era considerada juridicamente legal através do casamento entre homens e mulheres, ou seja, através de casais heterossexuais. Com o passar dos anos, esse fato foi se alterando, sofrendo mudanças relativamente aceita por todos, pois atualmente a sociedade conta com o exame de DNA, pois nele podemos chegar a uma verdade absoluta de quase $100 \%$ de quem realmente é o pai da criança (TARTURCE, 2012, p. 89).

Atualmente, temos o reconhecimento da paternidade sem o exame de DNA, a qual chamamos de paternidade não consanguínea, mas sim a paternidade derivada de afeto, atenção e cuidados com o menor, tratada legalmente como Paternidade Socioafetiva, que antigamente era bem questionada no ordenamento jurídico brasileiro. Sendo que nos dias atuais a Paternidade Socioafetiva, é amplamente aceita no meio jurídico através de jurisprudências e também perante a sociedade.

A formulação da palavra paternidade é devidamente fracionada no que tange o meio jurídico, biológico e socioafetivo, sendo que no meio jurídico ocorreu a evolução da paternidade que era tão a somente paternidade biológica, que agora passou a ter também a paternidade socioafetiva, a qual se prevalece e muito no nosso ordenamento jurídico brasileiro.

Destarte, notamos que a filiação não é somente através dos laços biológicos, ou seja, não tem somente o vínculo biológico, mas fica evidenciado a existência do vínculo socioafetivo, tendo em vista o melhor interesse da criança e da dignidade da pessoa humana e devidamente a paternidade responsável, ao qual esse pai assume todos os deveres referente ao menor (SARMENTO, 2008, p. 778).

A Paternidade Socioafetiva tem fundamentos nos comportamentais, culturais e sociais, ocorridos ao longo dos anos, tratando-se de caracterizar devidamente a forma de acolhimento desse filho, independente de que haja uma imposição 
jurisdicional ou vinculo sanguíneo, o vínculo de ambos são através dos sentimentos mais nobres existentes na humanidade o amor, o carinho e o mais importante o vínculo da convivência familiar que muitas das vezes são quebrados através da separação de seus pais biológicos e através da adoção esses filhos terão o amparo, atenção e conforto (SARMENTO, 2008, p.780).

Por fim, notamos que atualmente não temos somente o pai biológico ou consanguíneo, temos o Pai Socioafetivo podendo ser de origem biológica ou não, ou seja, é um vínculo que visa a proteção integral da criança e do adolescente, tendo direito e dever perante os pais e os filhos. Dessa forma esse pai deverá proporcionar a esse filho o acesso aos direitos fundamentais conforme descreve o art. 227 da Constituição Federal de 1988.

Com a Resolução n.ำ 175 do Conselho Nacional de Justiça, na qual estabelece que todos os Cartórios podem e devem celebrar a união estável do mesmo sexo, houve um grande avanço nas questões de adoção socioafetiva, pois muitas pessoas que desejavam ter filhos nesse tipo de relacionamento de união do mesmo sexo não era bem aceita pela sociedade e hoje esses casais do mesmo sexo podem ter filhos registrados com ambos os nomes na certidão,sob o manto da dupla paternidade no Registro Civil.

\subsection{Filiação e a Paternidade}

A filiação sempre esteve nesse passar dos anos como uma forma de preservar a família legitima, ou seja, os filhos que eram nascidos advindo do casamento dos pais eram tratados diferentemente dos filhos que o pai tinham fora do relacionamento conjugal, pois eram tratados como filhos legítimos os quais tinham todas as garantias jurídicas dos bens de seus pais, tratando de uma paternidade presumida de fato. Já os filhos nascidos fora do casamento eram tratados como filhos ilegítimos e eram considerados bastardos e tinham uma categoria inferior aos demais filhos desse pai, eram tratados como filhos incertos, ou seja, poderiam ser de qualquer um e não tinha qualquer tipo de direito a não ser se esse pai o garantisse, haja vista que existia uma proibição legal do reconhecimento desse filho, pois haveria por todo custo preservar o bem estar da família (FARIAS E ROSENVALD, 2008, p.690). 
Com o passar dos anos a sociedade começou a perceber e ter uma solidariedade a esses filhos advindos fora do casamento, passando a ter um novo ponto de vista acerca desses filhos usando os princípios constitucionais do nosso País.

De acordo com Nelson Rosenvald, 2013, p. 691, diz que pai afetivo é:

[...] aquele que ocupa, na vida do filho, o lugar do pai (a função). É uma espécie de adoção de fato é aquele que ao dar abrigo, carinho, educação, amor... ao filho, expõe o foro íntimo da filiação, apresentando-se em todos os momentos, inclusive naqueles e que se toma a lição de casa ou verifica o boletim escolar. Enfim, é o pai das emoções, dos sentimentos e é o filho do olhar embevecido que reflete aqueles sentimentos que sobre ele se projetam. (ROSENVALD E FARIAS, 2013, p.691)

Exclusivamente a filiação nada mais é que um vínculo jurídico que linha os filhos aos pais, mostrando-se assim a descendência familiar do mesmo, demonstrando-se assim o vínculo materno e paterno desses filhos.

Já Belmiro Pedro Welter, 2009, p. 122, fala que:

[...] não ser correto afirmar, como faz a atual doutrina e jurisprudência do mundo ocidental, que "a paternidade socioafetiva se sobrepõe à paternidade biológica" ou que "a paternidade biológica se sobrepõe à paternidade socioafetiva", isso porque ambas as paternidades são iguais, não havendo prevalência de nenhuma delas [...](WELTER, 2009, p. 122)

Com o passar dos tempos os juristas foram obrigados a reexaminar 0 conceito de família em nossa sociedade, com isso começaram a reconhecer as famílias construídas através da união estável e também as famílias monoparental, demonstrando que o afeto é superior a qualquer lações ou paradigmas sociais.

Haja visto, que uma criança somente pode ser chamado de filho se for de pais biológicos ou adotado, tendo ou não vínculo consanguíneo entre os genitores. Mas todavia a filiação vai muito além de genética entre pais e filhos, tem o amor o carinho, as responsabilidades dos pais perante essas crianças, demonstrando que o conceito jurídico sempre será pelo bem estar do menor, sendo na sua família consanguínea ou não. 


\subsection{A Paternidade no Registro Civil}

O Código Civil de 2002, no seu artigo 1.603, estabelece que a filiação é comprovada meramente com a apresentação do Registro de Nascimento o que podemos dizer que é verdade juridicamente.

Para fazer tal registro da criança o pai ou a munidos dos documentos pessoais dos mesmo juntamente com a certidão de casamento e a declaração de nascidos vivos da criança podem ir ao cartório ou a um departamento registral no próprio hospital que a mãe esteja internada com a criança. No caso do casal não serem casados os dois deverão comparecer, ou a mãe da criança no momento do registro da criança informa o nome do pai e seus dados para que assim o Cartório de Tabelionato e Registro Civil informe o judiciário e ao Ministério Público para que a criança tenha o nome dos dois genitores em seus documentos pessoais.

Haja vista que depois de registrada a criança esse ato de reconhecimento não poderá ser revogável como descreve o artigo 1610 do C.C de 2002: O reconhecimento não pode ser revogado, nem mesmo quando feito em testamento (BARROSO, 2013, p. 97).

Ademais, apesar da nossa Constituição Federal vedar a diferenciação dos filhos advindos ou não do matrimonio, os legisladores com uma visão de consagração da família ao criar o Código Civil de 2002 é bem preconceituoso a esse quesito e trata desse assunto diferente como Filiação sendo os filhos nascidos através do casamento conforme demonstra nos artigos 1.596 a 1.606 do CC de 2002 e do reconhecimento dos filhos conforme descreve os artigos 1.607 a 1.617 do CC de 2002, para eles essa separação era necessária para a preservação do conceito familiar e com toda pureza que é demonstrada em livros do século antigo(ALMEIDA, 2010).

A Constituição Federal de 1988, no seu artigo 227 trata que o Registro de Nascimento deve ser realizado para que a criança tenha total garantia para seu desenvolvimento como filho e que o mesmo tenha total atenção, carinho e afeto dos genitores, dessa forma, a criança terá garantido o seu princípio da dignidade da pessoa humana, ou seja, terá todo o amparo necessário para 0 seu desenvolvimento e crescimento. 
Ademais, poderemos notar que no campo teremos grandes desenrolamentos no campo jurídico em relação ao bem estar desse filho em relação a obrigação o pai seja ele biológico, adotante ou socioafetivo, pois na questão da guarda do filho será concedida aquele responsável que a criança ficará mais segura e que tiver as melhores condições financeiras e psicológicas para o bem estar do menor.

Para um ação de alimentos será conferido ao genitor registral, ou seja, ao pai que encontra-se no registro de nascimento, esse pai que deverá recair a obrigação alimentar, mesmo que esse pai tente negar a sua paternidade no processo de alimentos, que até o final do seu tramite o mesmo ainda será responsável pela criança, findando essa obrigação somente após a averbação da decisão em cartório de registros e tabelionado, mas o que atualmente vemos nas decisões jurídicas que muitas dessas decisões pleiteiam o interesse da criança, pois muitas das vezes os juízes zelam pela convivência do pai com o menor e que essa retirada do nome do pai nos documentos podem causar grandes problemas psicológicos a criança e com isso o pai mesmo não sendo o biológico pode continuar no registro, mas como pai socioafetivo dessa criança (FARIAS, 2013, p. 78).

Dessa forma, notamos que o artigo 1604 do Código Civil de 2002 estabelece que o Registro Civil só será invalido quando ocorrer um erro ou se houver falsificação, o registro no caso de adoção é um ato jurídico sem qualquer forma de vínculo com o registro antigo da criança, é uma certidão totalmente nova ao mesmo, onde os pais biológicos perdem todos os seus direitos e poderes familiares perante a criança, passando essas responsabilidades aos pais adotantes.

\subsection{Paternidade Socioafetiva}

O Direito de Família e Sucessões sofre grandes mudanças no decorrer dos anos, pois o mesmo se encontra sempre tentando se adequar as mudanças sociais para que dessa maneira possa se adequar o máximo possível nas relações existente.

Umas das grandes transformações é que as famílias não são mais vistas como sacras, religiosas, mas sim como uma relação de afeto e companheirismo, 
demonstrando que a evolução social mudou a família institucionalizada, para uma família solidária.

A relação pai e filho é observado a importância da formação do indivíduo em família sendo ela legítima, monoparental, homoafetiva ou até mesma a família formada pela união estável onde os filhos são capazes de receber amor e atenção independente do modelo familiar que ele se encontra.

Quanto a relação socioafetiva decorre da vontade de uma pessoa a dar amor e afeto a uma criança sem querer nada em troca, ou seja, é quando uma pessoa se candidata a ser pai ou mãe de uma criança somente porque deseja criar e dar total atenção que aquele filho não recebeu dos seus pais biológicos. Dessa forma,

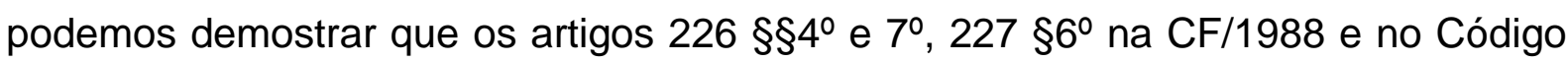
Civil os artigos 1593, 1596, 1597, V, 1603 e 1605, II, também podemos expressar que a vontade é totalmente irrevogável, exceto se ocorrer falsidade ou erro no Registro de Nascimento (PEREIRA, 2006, p.65).

Contudo, sabemos que a adoção é uma das formas mais antigas do direito para resguardar o direito daqueles casais que não puderam ter seus próprios filhos, a adoção nada mais é que um ato jurídico que tem requisitos legais ao qual os casais ou pessoas devem se enquadrar e esses candidatos a pais podem ou não ter lações consanguíneos, sendo que essa criança passará por um período de adaptação nessa nova família, garantindo ao adotante o laço de parentesco de $1^{\circ}$ grau de linha reta.

$\mathrm{Na}$ adoção socioafetiva o registro da criança não é retirado o nome dos pais biológicos e sim somente acrescentado o nome do pai socioafetivo, podendo a criança futuramente procurar seus laços biológicos tanto paterno ou materno, como também poderemos caracterizar essa adoção socioafetiva através do reconhecimento voluntario do pai ou da mãe consanguínea da criança, demostrando a observação que a criança será devidamente apresentado pelos familiares como filho e tratado também como filho e reconhecido publicamente como tal.

\subsection{Paternidade Biologica}

A filiação é a busca da identidade entre pai e filho, onde ambos iram conhecendo suas personalidades e necessidades como indivíduos de uma mesma 
família consanguínea. Ademais sabemos que muitos desses pais se relacionam basicamente sem compromissos com mulheres e quando as mesma informam que estão gravidas muito desses homens que são supostos pais dessas crianças se abstém dessa responsabilidade de ser pai desse filhos, com isso essas mães procuram a justiça para que esse homem seja devidamente obrigado a ter as devidas responsabilidades como genitor para esse filho que o não reconhece.

Com o passar dos anos essas mães tiveram um ganho significativo com esses supostos pais que foi a criação do exame de DNA, no qual determina com clareza de $99,99 \%$ de que ele é realmente pais daquele criança, com isso esse pais passa a ter total responsabilidade perante aquela criança e a mesma começa a ter seus direitos básicos garantidos.

A recusa do suposto pai em realizar o exame de DNA, a criança pode ser reconhecida da mesma maneira, pois a Súmula 301 do STJ e o artigo 232 do CC de 2002, essa criança terá o seu reconhecimento através da relação presumida, pois se o suposto pai se nega a fornecer o material genético o mesmo está presumindo que a criança é seu filho e não deseja se comprometer com essas obrigações junto ao menor.

\subsection{Família e o seu desenvolvimento conforme o Código Civil de 1916 e as suas devidas implantações através do Código Civil de 2002}

Notamos quanto é percebível a diferença existente da correlação a prisma da entidade familiar que descreve com a vigência do Código Civil de 2002 com as que existiam anteriormente com a constância do Código Civil de 1916,, onde as famílias apenas eram tratadas como entidades de economia agrícola e que a base dessas famílias eram apenas gerida pelo pai, onde ele era o arrimo da família e a mulher apenas poderia cuidar dos filhos e da casa e os filhos eram apenas os concebidos perante o casamento, filhos fora da família legitima eram considerados bastardos.

Todas as mudanças existentes no Código Civil em relação a família e sucessões se dão porque a sociedade está em constante mutações e dessa forma 
temos que ter leis que satisfação os direitos e vontades daqueles que anteriormente eram excluídos do reconhecimento de seus direitos familiares.

O nobre pensador Carlos Roberto Gonçalves, 2005, p. 16, diz que:

"O Código Civil de 1916 e as leis posteriores, vigentes no século passado, regulavam a família constituída unicamente pelo casamento, de modelo patriarcal e hierarquizada, ao passo que o moderno enfoque pelo qual é identificada tem indicado novos elementos que compõem as relações familiares, destacando-se os vínculos afetivos que norteiam a sua formação". (GONÇALVES, 2005, p. 16).

Com as mudanças estabelecidas pelo Código Civil de 2002, verificamos que tivemos inúmeras alterações no direito de família e sucessões, mas sempre demostrando nessas mudanças que as famílias são a base do Estado.

\subsection{Família advinda da Constituição Federal de 1988}

Na nossa Constituição Federal trata a família como um dos pilares de direitos básicos da sociedade ao qual trata-se dos direitos de igualdade, solidariedade entre outros dessa forma a família pode buscar vários direitos presentes em nossas leis e também os filhos dessas casais sejam de casamentos ou não direitos iguais entre si.

Com a criação da Constituição Federal de 1988 fora reconhecido a família monoparental onde nada mais é que apenas um dos genitores tem responsabilidade e criação do filho, dessa forma os pais solteiros passam a ter um amparo do Estado sendo essas famílias formadas através de separações ou inseminação artificial, mas perante a lei são constituídas da famílias.

Por fim, notamos que os legisladores constitucionais priorizaram na família o afeto como forma fundamental do princípio da dignidade da pessoa humana, pois a família tem função social e dessa forma o casal tem igualmente direito perante os filhos, pois anteriormente somente o pai tinha poder sobre o filho. 


\section{LEI DE REGISTROS PÚBLICOS}

Apropriadamente fica demonstra que o efetivo conceito de paternidade consente que mais de uma pessoa possa exercer esse direito, em relação a uma criança ou indivíduo, autorizando assim a explanação da Lei de Registros Públicos, para que se possa demonstrar a legalidade da dupla paternidade nos Registros no Brasil.

Ademais, destaca-se que a importância da lei no 6.015/73, consagra-se que os registros públicos é muito antiga até anterior a Constituição Federal de 1988, carecendo com urgência de uma mudança para que dessa forma a mesma possa se modernizar e adequar as mudanças atuais da sociedade brasileira e a diminuição das grandes demandas judiciais para acrescentar nomes dos devidos pais socioafetivos nos registros das crianças, adolescentes e pessoas no nosso país.

Todavia, apesar das grandes mudanças das grandes mudanças realizadas na referida lei desde a sua entrada em vigor, não se deram suficientemente para poder abraçar o avanço das mudanças que foram realizadas no âmbito do Direito de Família.

Dessa forma, notamos que a referida lei de Registros Públicos é controlada por uma legislação é longínqua a realidade atual da sociedade e do Direito de Família e Sucessões.

Dessa forma, disciplina a lei dos registros públicos nos demonstra que é maneada por uma legislação primitiva, ficando caracterizada que sempre ocorrerá a interpretação do legislador para que se possa adequar aos tempos atuais da sociedade.

Ademais, no artigo 60 da Lei 6.015/73, trata em relação a filiação que o "o registro conterá o nome do pai ou da mãe, ainda que ilegítimos, quando qualquer deles for o declarante". Denota-se, que o referido artigo fala que o nome do pai deverá constar no registro, sem determinar a quantidade ou o conceito real de pai.

Contudo, o legislador, juristas ou profissionais do direito deverão empregar a legislação de forma que sua legalidade seja mantida, juntamente com a consonância com as demais legislações pertinentes aos registros públicos e a família com suas mudanças sociais. Para isto, o julgador utilizará uma ferramenta muito utilizada atualmente que é a hermenêutica constitucional, demonstrando a necessidade 
social, que devidamente seria a dupla paternidade da criança, ferramenta essa muito positiva para adequação da norma e a sua adequação as demais normas existentes, e a consonância com os princípios constitucionais, buscando assim uma decisão justa e adequada para cada caso em seu efeito judicial concreto.

Demonstra-se sobre o tema o Ministro do STF Luis Roberto Barroso, na página 07, no ano de 2005 que:

\begin{abstract}
As denominadas cláusulas gerais ou conceitos jurídicos indeterminados contém termos ou expressões de textura aberta, dotados de plasticidade, que fornecem um início de significação a ser complementado pelo intérprete, levando em conta as circunstâncias do caso concreto. A norma em abstrato não contém integralmente os elementos de sua aplicação. Ao lidar com locuções como de ordem pública, interesse social e boa-fé, dentre outras, o intérprete precisa fazer a valoração de fatores objetivos e subjetivos presentes na realidade fática, de modo a definir o sentido e alcance da norma. Como a solução não se encontra integralmente no enunciado normativo, sua função não poderá limitar-se à revelação do que lá se contém; ele terá de ir além, integrando o comando normativo com a sua própria avaliação (BARROSO, 2005, p.7).
\end{abstract}

À vista disso, a lei de registros públicos é bastante vaga, pois dispõe somente que o pai constará no registro da pessoa, mas sem qualquer esclarecimentos acerca da paternidade e seus especificações e quantidade, trazendo assim muitas lides no judiciários, pois, desta forma, o juiz deverá aplicar o que será mais benéfico ao desejo pleiteado e terá que delimitar a quantidade de pessoas no registro da criança, trazendo assim uma nova concepção constitucional e uma grande valorização de sua abrangência.

Para melhor aplicação da lei nas mudanças do direito e da família contemporânea o conceito de paternidade deverá ser feita basicamente a convergência do artigo 60 da Lei n. $6.015 / 73$ que é abstrata a este sentido com os conceitos apresentados nas doutrinas e jurisprudências, prevalecendo as mudanças da atualidade.

Atualmente o conceito de paternidade no direito de família proporciona que a paternidade possa ser exercida por um ou mais indivíduo em relação a uma única pessoa, mas a lei apenas apresenta que o pai deverá constar no registro sem se quer apresenta qualquer restrições a quantidade, devendo dessa maneira permitir a dupla paternidade da pessoa a qual a pleiteia. 
Aponta-se, afinal que o jurisprudência e o ordenamento jurídico já se evoluem ao reconhecer a inserção do nome do segundo pai no registro do filho, dessa forma vemos na lei de registro público sofrera uma alteração significante através da Lei n.o 11.924/09 que incluiu o parágrafo 8 no artigo 57 da Lei 6.015/73 permitindo que o enteado possa colocar o nome de seu padrasto no seu registro de nascimento.

Por fim, fica claro que o reconhecimento dos juristas nessa inclusão do nome de mais um pai ao registro de nascimento da criança, mesmo essa criança tendo ou não vinculo de afetividade com o genitor, ele poderá optar por ter uma relação socioafetiva com esse padrasto e dessa maneira podendo ter ele presente não somente na vida e no seu cotidiano, mas também inserido nos seus documentos o nome de seu padrasto. Conclui-se que podemos verificar que o Direito de Família atual e o conceito de família estão atrelados na norma jurídica da lei 6.015/73 e com grande amparo do ordenamento jurídico ao que descreve a dupla paternidade.

\subsection{O Registro Civil e a Dupla Paternidade no Brasil}

A partir de meados de 2016, com o diapasão do STF, se tornou possível a dupla paternidade a ser inserida no registro civil da criança e de qualquer cidadão brasileiro. Dessa maneira, ficando evidenciado a permissão da inclusão do pai biológico e do socioafetivo, em todos os documentos do filho ou da pessoa que buscou tal direito.

Portanto, tal decisão foi através de uma análise de um Recurso Extraordinário (RE 898060) no qual a criança buscou após descobrir que não era filha biológica do pai que estava descrito em seu registro de nascimento, dessa forma, a mesma pleiteou o ingresso do nome do pai biológico e deixando o pai do registro como seu pai socioafetivo, ou seja, mantendo o nome do seu pai de criação e pleiteando também que o pai biológico fosse obrigado a arcar com parte dos seus gastos financeiros, sendo assim, ficando obrigado ao pagamento de pensão alimentícia.

A incompatibilidade, da defesa do pai biológico, questionou que por a filha ter sido criada por terceiros, ou seja, outro pais, essa filha foi acolhida por outra pessoa e que por esse motivo ela não poderia receber qualquer ajuda do pai biológico e também não teria o direito de ter sua herança no momento da morte do 
genitor, ainda afirmando que o pai socioafetivo deveria ser considerado o pai por direito e também devendo continuar arcando com as despesas financeiras da filha. Fato esse demonstrando total desafeto e abandono desse pai biológico a filha que não somente a abandonou no ventre, mas que agora lhe abandona em vida.

Contudo, o STF, não aceitou as alegações da defesa do pai biológico, e ainda determinou que o mesmo começasse a efetuar o pagamento dos alimentos a requerente que ora é filha biológica do mesmo e que o seu devido registro civil fosse alterado e passasse a conter o nome dos dois pais.

Ademais, pela grande repercussão geral do fato, o STF, sancionou a seguinte tese:

\footnotetext{
"A paternidade socioafetiva, declarada ou não em registro público, não impede o reconhecimento do vínculo de filiação concomitante baseado na origem biológica, com os efeitos jurídicos próprios".
}

No decorrer, desse entendimento, estima-se o salvo-conduto dos direitos do pai socioafetivo, haja, vista que sua atitude honrosa na criação da menor, não tendo qualquer laço consanguíneo com a mesma, criando-a apenas pelo laço de amor que nutria com a mesma, sempre a protegendo e zelando-a como filha, também simultaneamente exigindo que essa filha que o pai biológico a colocou no mundo arcasse com as devidas responsabilidades e consequências de seus atos, perante a menor.

Por fim, nota-se que o STF, deixa claro que a paternidade socioafetiva, não terá uma prerrogativa de poder suprir as obrigações advindas da paternidade biológica, no que seria plenamente proporcionado com o que determina a legislação constitucional, haja vista, que a legislação de forma alguma distingue os filhos, sendo eles biológicos ou não.

Ficando assim, evidenciado que não caberá ao legislador e as leis, obrigar que esses pais biológicos amem seus filhos, mas podendo assim determinar que os mesmo possam dar um amparo e o zelo, mesmo que seja financeiro, para com esses filhos, não sendo mais razoável de uma obrigação paterna. 


\section{A DUPLA PATERNIDADE ATRAVÉS DP RECURSO EXTRAORDINÁRIO № 898.069}

Precedentemente, a qualquer explanação sobre o referido tema, iremos abordar sobre o Princípio da igualdade entre os Filhos, haja vista, que a nossa Constituição Federal de 1988, trata de impulsionar e proporcionar o diálogo e as devidas pretensões de que a sociedade busca para as mudanças e pelas modificações das legislações que estão inseridas nas mudanças da sociedade contemporânea existente em nosso país.

Dessa forma, notamos que o artigo 227, § 6으 da Constituição Federal de 1988 trata-se que, "os filhos, havidos ou não da relação do casamento, ou por adoção, terão os mesmos direitos e qualificações, proibidas quaisquer designações discriminatórias relativas à filiação", contudo notamos que o legislador tenta de todas as formas legais diminuir a diferenciação de tratamentos dos filhos advindos ou não de um relacionamento duradouro entre os pais, mostrando que os filhos terão os menos direitos e deveres, passando a valorizar não somente as famílias mas também a seus aspectos de afetividades.

Nesta oportunidade, podemos sustentar que qualquer filho gozará de todos os devidos direitos em relação aos pais, como seus direitos de proteção. Dessa maneira, todos os recursos legais, direta ou indiretamente, trata diferenciadamente entre os filhos, contudo essas diferenciações devem ser totalmente suprimas pelo ordenamento jurídico, tornando os filhos um tratamento pleno de total igualdade dentro a entidade familiar, sendo eles filhos consanguíneos ou adotivos todos serão tratados como legítimos, promovendo a dignidade e igualdade dos filhos.

Ademias, enquanto a legislação brasileira não tenha sancionado qualquer legislação a respeito da proteção dos filhos socioafetivos, os tribunais de justiça de todo o país se utilizam do princípio da dignidade da pessoa humana o reconhecimento do vínculo e da igualdade desses filhos perante aos demais filhos consanguíneos. Neste sentido podemos notar a ementa do processo civil julgado pelo STF:

"Civil e Processual Civil. Recurso Especial. Família. Reconhecimento de Paternidade e Maternidade Socioafetiva. Possibilidade. Demonstração. 1. A paternidade ou maternidade socioafetiva é concepçãojurisprudencial e doutrinária recente, ainda não abraçada, 
expressamente, pela legislação vigente, mas a qual se aplica, de forma analógica, no que forem pertinentes, as regras orientadoras da filiação biológica. 2. A norma princípio estabelecida no art. 27, in fine, do ECA afasta as restrições à busca do reconhecimento de filiação e, quando conjugada com a possibilidade de filiação socioafetiva, acaba por reorientar, de forma ampliativa, os restritivos comandos legais hoje existentes, para assegurar ao que procura o reconhecimento de vínculo de filiação sociafetivo, trânsito desimpedido de sua pretensão. 3. Nessa senda, não se pode olvidar que a construcão de uma relação socioafetiva, na qual se encontre caracterizada, de maneira indelével, a posse do estado de filho, dá a esse o direito subjetivo de pleitear, em juízo, o reconhecimento desse vínculo, mesmo por meio de ação de investigação de paternidade, a priori, restrita ao reconhecimento forçado de vínculo biológico. [...]" (Superior Tribunal de Justiça - Terceira Turma/ REsp 1.189.663/RS/ Relatora Ministra Nancy Andrighi/ Julgado em 06.09.2011/ Publicado no DJe em 15.09.2011).

"Direito civil. Família. Recurso Especial. Ação de anulação de registro de nascimento. Ausência de vício de consentimento. Maternidade socioafetiva. Situação consolidada. Preponderância da preservação da estabilidade familiar. [...] - O descompasso do registro de nascimento com a realidade biológica, em razão de conduta que desconsidera o aspecto genético, somente pode ser vindicado por aquele que teve sua filiação falsamente atribuída e os efeitos daí decorrentes apenas podem se operar contra aquele que realizou 0 ato de reconhecimento familiar, sondando-se, sobretudo, em sua plenitude, a manifestacão volitiva, a fim de aferir a existência de vínculo socioafetivo de filiação. Nessa hipótese, descabe imposição de sanção estatal, em consideracão ao princípio do maior interesse da criança, sobre quem jamais poderá recair prejuízo derivado de ato praticado por pessoa que lhe ofereceu a segurança de ser identificada como filha. - Some-se a esse raciocínio que, no processo julgado, a peculiaridade do fato jurídico morte impede, de qualquer forma, a sanção do Estado sobre a mãe que reconheceu a filha em razão de vínculo que não nasceu do sangue, mas do afeto. - Nesse contexto, a filiação socioafetiva, que encontra alicerce no art. 227 , $\S 6^{\circ}$, da $\mathrm{CF} / 88$, envolve não apenas a adoção, como também " parentes com os de outra origem", conforme o pelo art. 1.593 do CC/02, além daqueles decorrentes da consanguinidade oriunda da ordem natural, de modo a contemplar a socioafetividade surgida como elemento de ordem cultural. - Assim, ainda que despida de ascendência genética, a filiação socioafetiva constitui uma relação de fato que deve ser reconhecida $e$ amparada juridicamente. Isso porque a maternidade que nasce de uma decisão espontânea deve ter guarida no Direito de Família, assim como os demais vínculos advindos da filiação. - Como fundamento maior a consolidar a acolhida da filiação socioafetiva no sistema jurídico vigente, erige-se a cláusula geral de tutela da personalidade humana, que salvaguarda a filiação como elemento fundamental na formação da identidade do ser humano. Permitir a desconstituição de reconhecimento de maternidade amparado em relação de afeto teria o condão de extirpar da criança - hoje pessoa adulta, tendo em vista os 17 anos de tramitação do processo - preponderante fator de construção de sua identidade e de definição de sua personalidade. E a identidade dessa pessoa, resgatada pelo afeto, não pode ficar à deriva em face das incertezas, instabilidades ou até mesmo interesses meramente patrimoniais de terceiros submersos em conflitos familiares. [...]" (Superior Tribunal de Justiça - Terceira Turma/ REsp 1.000.356/SP/ Relatora Ministra Nancy Andrighi/ Julgado em 25.05.2010/ Publicado no DJe em 07.06.2010). 
Portanto, notamos que esse estilo de paternidade, nada mais é que uma paternidade que sobrevêm da paternidade dos lações consanguíneos, haja vista, as grandes mutações e alterações familiares da atualidade. Assim, quando muitos relacionamentos termina da mesma forma que a família, muitos desses pais, não assumem a paternidade desses filhos advindos desses relacionamentos, muitas das vezes não assumem nem ao papel de paternidade do filho biológico e nem o do adotivo.

Dessa forma muitos, pais não consanguíneos assumem a paternidade, tornando esse filho como parte da sua família, Ihe dando atenção, amparo, afeto, revelando a grande importância do amor e a atenção para o melhor desenvolvimento da criança na sociedade. Dessa maneira, foi o entendimento do Supremo Tribunal Federal em explicar o reconhecimento da união homo afetiva, haja vista, que essa devida união tem como alicerce o amor e o respeito mútuo entre os indivíduos.

Como podemos verificar no trecho do livro de Daniel Sarmento,2008, p. 649, que salienta:

"Enfim, se a nota essencial das entidades familiares no novo paradigma introduzido pela Constituição de 88 é a valorização do afeto, não há razão alguma para exclusão das parcerias homossexuais, que podem caracterizar-se pela mesma comunhão e profundidade de sentimentos presentes no casamento ou na união estável entre pessoas de sexos opostos, não existindo, portanto, qualquer justificativa legítima para a discriminação praticada contra os homossexuais" (DANIEL SARMENTO, 2008, p. 648).

Ademias, podemos dizer que não se trata meramente da dedicação afetiva para que possa se construir uma ligação paterna e filial, mas é preciso basicamente um afeto capaz de extrapolar qualquer vínculo biológico, se tornando um componente decisivo para concepção de um vínculo intelectual e afetuoso, causando dessa forma um relacionamento com um dialogo sobre os projetos de vida e construção pessoal desse filho. Podendo assim, o orientar e trilhar seus caminhos na sociedade de bem, demonstrando e ensinando os critérios socioafetivos e demonstrando suas preocupações e esperanças no crescimento da criança ou do adolescente.

Neste tocante Rolf Madaleno defende que: 
"Maior prova da importância do afeto nas relações humanas está na igualdade da filiação (art. 1.596, CC), na maternidade e paternidade socioafetivas e nos vínculos de adoção, como consagra esse valor supremo ao admitir outra origem de filiação distinta da consanguínea (art, 1.593, CC), ou ainda através da inseminação artificial heteróloga (art. 1.597, V, CC); na comunhão plena de vida, só viável enquanto presente o afeto, ao lado da solidariedade, valores fundantes cuja soma consolida a unidade familiar, base da sociedade a merecer prioritária proteção constitucional"

Por fim, fica evidenciado que ao registrar a filiação com base no vínculo socioafetivo, vai ficar caracterizada a relação entre as devidas pessoas envolvidas, dessa forma, afastando por definitivo o vínculo biológico, por esta razão, a pessoa adotada não poderá pleitear verbas alimentares e nem participar da herança do genitor.

\subsection{O Direito e a Jurisprudência a Responsabilidade a Respeito da Dupla}

\section{Paternidade}

O Provimento 63/2017 do CNJ (Conselho Nacional de Justiça) pacifica a oportunidade de legalização da paternidade ou maternidade socioafetiva, em face dos oficiais de registro civil de pessoas naturais, demonstrando que o reconhecimento não se trata meramente de dois pais ou duas mães, trazidos no assento de nascimento, mas também servirá para os casos que não constar o nome do genitor ou genitora no registro.

Sobre a paternidade socioafetiva o Provimento determina que:

Art. 10. O reconhecimento voluntário da paternidade ou da maternidade socioafetiva de pessoa de qualquer idade será autorizado perante os oficiais de registro civil das pessoas naturais

$\S 1^{\circ} \mathrm{O}$ reconhecimento voluntário da paternidade ou maternidade será irrevogável, somente podendo ser desconstituído pela via judicial, nas hipóteses de vício de vontade, fraude ou simulação.

$\S 2^{\circ}$ Poderão requerer $\mathrm{o}$ reconhecimento da paternidade ou maternidade socioafetiva de filho os maiores de dezoito anos de idade, independentemente do estado civil.

$\S 3^{\circ}$ Não poderão reconhecer a paternidade ou maternidade socioafetiva os irmãos entre si nem os ascendentes.

$\S 4^{\circ}$ O pretenso pai ou mãe será pelo menos dezesseis anos mais velho que o filho a ser reconhecido.

Art. 11. O reconhecimento da paternidade ou maternidade socioafetiva será processado perante o oficial de registro civil das pessoas naturais, ainda que diverso daquele em que foi lavrado o assento, mediante a exibição de documento oficial de identificação com foto do requerente e da certidão de nascimento do filho, ambos em original e cópia, sem constar do traslado menção à origem da filiação. 
$\S 1^{\circ} \mathrm{O}$ registrador deverá proceder à minuciosa verificação da identidade do requerente, mediante coleta, em termo próprio, por escrito particular, conforme modelo constante do Anexo VI, de sua qualificação e assinatura, além de proceder à rigorosa conferência dos documentos pessoais.

$\S$ 2o $O$ registrador, ao conferir o original, manterá em arquivo cópia de documento de identificação do requerente, juntamente com o termo assinado.

$\S$ 3ํㅡㄴ Constarão do termo, além dos dados do requerente, os dados do campo FILIAÇÃO e do filho que constam no registro, devendo o registrador colher a assinatura do pai e da mãe do reconhecido, caso este seja menor.

$\S 4^{\circ}$ Se o filho for maior de doze anos, o reconhecimento da paternidade ou maternidade socioafetiva exigirá seu consentimento.

$\S 5^{\circ}$ A coleta da anuência tanto do pai quanto da mãe e do filho maior de doze anos deverá ser feita pessoalmente perante o oficial de registro civil das pessoas naturais ou escrevente autorizado.

$\S 6^{\circ} \mathrm{Na}$ falta da mãe ou do pai do menor, na impossibilidade de manifestação válida destes ou do filho, quando exigido, o caso será apresentado ao juiz competente nos termos da legislação local.

$\S 7^{\circ}$ Serão observadas as regras da tomada de decisão apoiada quando o procedimento envolver a participação de pessoa com deficiência (Capítulo III do Título IV do Livro IV do Código Civil).

$\S 8^{\circ}$ O reconhecimento da paternidade ou da maternidade socioafetiva poderá ocorrer por meio de documento público ou particular de disposição de última vontade, desde que seguidos os demais trâmites previstos neste provimento.

Art. 12. Suspeitando de fraude, falsidade, má-fé, vício de vontade, simulação ou dúvida sobre a configuração do estado de posse de filho, o registrador fundamentará a recusa, não praticará 0 ato e encaminhará o pedido ao juiz competente nos termos da legislação local.

Art. 13. A discussão judicial sobre o reconhecimento da paternidade ou de procedimento de adoção obstará o reconhecimento da filiação pela sistemática estabelecida neste provimento.

Parágrafo único. O requerente deverá declarar o desconhecimento da existência de processo judicial em que se discuta a filiação do reconhecendo, sob pena de incorrer em ilícito civil e penal.

Art. 14. O reconhecimento da paternidade ou maternidade socioafetiva somente poderá ser realizado de forma unilateral e não implicará o registro de mais de dois pais ou de duas mães no campo FILIAÇÃO no assento de nascimento.

Art. 15. O reconhecimento espontâneo da paternidade ou maternidade socioafetiva não obstaculizará a discussão judicial sobre a verdade biológica."

Ademais, não poderá deixar de destacar que a referida decisão envolverá também os bens patrimoniais, desse reconhecimento, mas nos devidos aspectos morais e éticos, o pai socioafetivo estará ciente de que o filho é um filho de afeto e não biológico, e caso rompa o relacionamento com a genitora ou genitor da criança, a criança poderá ir a juízo requerer a anulação da paternidade.

O devido Provimento, apenas regula o reconhecimento da nova realidade da sociedade proveniente da evolução da sociedade, devendo dessa forma, amparando todas as modalidades de família, sendo, a matriarcal, homoafetiva, heteroafetiva e Monoparental, advinda de qualquer pessoas que tenham a formalidade de um 
vínculo afetivo. Portando também temos as famílias substitutas advindas da adoção, sendo elas permanentes ou temporárias, mas que criam os mesmos laços afetivos com a criança ou o menor.

Por fim, denota-se a iqualdade existente entre os procedimentos descritos no processo de adoção no ECA, com o que determina o Código Civil Brasileiro, definindo em regra a adoção cartorária, dessa forma, exclui a obrigação de um processo judicial, bem como os amparos da segurança jurídica, ou seja, a partipação do Ministério Público e bem como o Advogado, nesses casos.

\subsection{Diversidades de Opiniões Advinda do Reconhecimento da Dupla Paternidade, Advinda do STF}

Em setembro de 2016, o Supremo Tribunal Federal (STF) atribuiu, por sua grande maioria dos votos dos ministros daquele plenário, a multipaternidade a uma pessoa, Ihe proporcionado a dupla paternidade em seu registro de nascimento, ou seja, a partir daquela data a pessoa hoje com mais de trinta anos de idade, passaria a contar com o nome de dois pais em seu registro civil.

Ademais, essa autorização, posteriormente jurisprudência, somente foi reconhecida, após a menina na sua adolescência descobrir que o pai ao qual the criava não seria seu genitor biológico, mas que o nome que constava em seu registro de nascimento era de seu pai de criação, ou seja, o pai socioafetivo, dessa maneira a adolescente ingressou com um processo judicial ao qual queria que seu registro constasse 0 nome do pai biológico e que o mesmo the ajudasse financeiramente., mas que o seu, por maioria de votos, a dupla paternidade a uma mulher, possibilitando que ela tenha dois pais registrados: o pai biológico e o pai socioafetivo. Dessa forma, o procurador do pai biológico, recorreu ao STF, solicitando a determinação que o pai socioafetivo deveria continuar arcando sozinho com os gastos financeiros da adolescente.

Mas, para a surpresa do procurador do pai biológico, o entendimento do STF, fora que a presença do pai socioafetivo, não exclui as devidas responsabilidades civis e financeiras que o genitor biológico do filho tem com o mesmo. Como demonstra no entendimento dos Ministros do STF, Luiz Fux e Carmem Lucia, descritos simultaneamente: "não existe impedimento do reconhecimento simultâneo 
das duas formas de paternidade desde que isso seja do interesse do filho". Já a presidente do STF, descreve que "amor não se impõe, mas cuidado sim e esse cuidado me parece ser do quadro de direitos que são assegurados, especialmente no caso de paternidade e maternidade responsável".

Por fim, fica demonstrada que essa decisão, causa repercussão geral, ficando jurisprudencial o uso da mesma por demais magistrados brasileiros a pessoas que buscarem a justiça para terem tal direitos semelhantes ao tema pertinente. 


\section{4 É POSSíVEL O RECONHECIMENTO DA FILIAÇÃO COM A DUPLA PATERNIDADE}

A partir da decisão do STF, sobre outras formas de famílias no Brasil, fora progredindo os direitos das minorias ou seja, os casais homoafetivos, pois, dessa forma, eles estão conquistando importantes avanços no poder judiciário, as definições de família está em grande mutação em todo o mundo e seria inelutável essas mudanças e uniões não fossem devidamente amparadas e reconhecidas por lei, tratando todos assim com a igualdade que determina a Constituição Federal Brasileira de 1988.

Nessa acepção, o reconhecimentos de filhos com a dupla paternidade em famílias homoafetivas ou em famílias heteroafetivas, se torna um avanço ao caminho trilhado por esses casais para a construção familiar com a geração de filhos biológicos ou adotivos, caminho esse já sem volta, pois o avanço judicial nesse contexto, estão paralelos com as mudanças da sociedade.

Ademais, as famílias heteroafetivas, podendo ser compostas com dois pais e uma mãe, ou vice versa, podem ser analisadas a inclusão do nome desse pai ou mãe socioafetiva no registro dessa criança, podendo ocorrer esse fato de inclusão quando um dos genitores falecem ou até mesmo quando ocorre uma separação dos pais biológicos, ocorrendo com um abandono emocional de um dos genitores no rompimento da relação.

Diante disso, mostra-se dúvidas a respeito da possibilidade do real reconhecimento dos filhos pela dupla paternidade, todavia, não existindo qualquer legislação pertinente ao tema da dupla paternidade, mas não querendo dizer que não existiria a possibilidade de reconhecimento para tais fatos.

Entretanto, as uniões homoafetivas, podem avançar ainda mais perante a sociedade, pois cada vez mais eles terão reconhecidos os seus direitos como casal e dessa forma facilitando a formação de uma família e o devido reconhecimento desses filhos advindos de fertilização e da união deles, tornando assim legal a dupla paternidade ou maternidade no País. 
Contudo, os casais homoafetivos, que por ventura tivessem filhos pela forma de reprodução assistida teria os filhos registrados pelo nome dos dois, mas por meio judicial.

Haja vista, que a reprodução assistida é autorizada e prevista em lei, ou seja, a Resolução 2.121/15 do CRM, regula as devidas normas médicas para tal procedimento, incluindo os casais homoafetivos.

Todavia, o Código Cível e nem o Código de Processo Cível, não dispõem de previsões legais a respeito do tema de reprodução assistida e nem da dupla paternidade por heteroafetivos e homoafetivos, como não tem uma legislação pertinente ao caso, os cartórios de registros civis, se recusam a fazer o primeiro registro com o nome da dupla paternidade.

Agora com o recente Provimento editado pelo Conselho Nacional de Justiça Provimento n63/2017 já é possível esse registro nos cartórios, pois permite o reconhecimento voluntário socioafetivo e que antes a possibilidade de garantir tal feito, seria ingressar com uma ação judicial, para poder buscar tal direito e reconhecimento com a criança ainda no ventre da mãe, assim, garantiria o direito da criança ter o nome dos dois pais no seu primeiro registro de nascimento. 


\section{CONCLUSÃO}

A complexidade e o dinamismo atribuído as novas relações de família faz com que surgem o reconhecimento de paternidade socioafetiva, onde laços de afeto independentemente de vinculo biológico está presente no cotidiano do filho, trata-se portanto de uma paternidade responsável positivada pela nossa carta magna em seu artigo $226 \S 7^{\circ}$ e fundada no Princípio da Dignidade humana.

As novas concepções de família que perfaz no Princípio da Dignidade da Pessoa humana e Princípio da Efetividade formam novas formas de constituição familiar que a nossa própria Constituição Federal em seu artigo $226 \$ 4^{\circ}$ define como entidade familiar a comunidade formada por qualquer dos pais e seus descendentes. No entanto essas mudanças no Direito de Família se tornam cada vez mais constantes e com a necessidade de preservar a instituição familiar adequando-se também as necessidades da sociedade e principalmente o interesse do menor.

O legislador regulamentou as entidades familiares mas esqueceu de normatizar de forma clara esse tipo de paternidade no nosso ordenamento jurídico gerando assim buscas incessantes no direito pátrio afim de resolver o impasse no registro público e se tornar possível a declaração no registro de nascimento do filho , enquanto o legislador não preenche as lacunas existentes no Direito Pátrio os tribunais se utilizam de hermenêutica jurídica sempre em favor do interesse da criança respaldada na Dignidade da Pessoa humana e na proteção regulamentada pelo Estatuto da criança e do adolescente.

Portanto, conclui-se com o presente trabalho entender o novo entendimento e posições adotadas à respeito da filiação no registro Civil em que pese a dupla paternidade sendo ela por famílias heterossexuais ou em famílias homossexuais afim de tornar uma realidade fenomênica seja através de interpretação pluralista e aberta dos dispositivos constitucionais que guardem correspondência com os princípios fundamentais do Estado democrático de Direito.

Conclui-se que a dupla paternidade coincide com uma situação que anda aparecendo com grande frequência em nossa cultura e sociedade, solicitando assim uma adequação do direito, para que assim demonstre um amparo jurídico perante as necessidades da população. Devendo, dar um amparo aquele filho, pois não é 
plausível que um filho tenha que excluir um pai para poder colocar outro em seu registro civil, pois dessa forma, estará excluindo ele da sua vida.

Dessa maneira, a dupla paternidade, demonstra ser uma realidade na sociedade civil, merecendo assim a tutela estatal, para que possa promover e assegurar os princípios Constitucionais, previstos tais como o da igualdade e da dignidade da pessoa humana. 


\section{REFERÊNCIAS}

ALMEIDA, Renata Barbosa de; JÚNIOR, Walsir Edson Rodrigues. Direito Civil: Famílias. Rio de Janeiro: Lumen Juris, 2010.

BARROSO, Luís Roberto. Neoconstitucionalismo e constitucionalização do Direito: o triunfo tardio do Direito Constitucional no Brasil. Disponível em: <http://jus.com.br/revista/texto/7547>. Acesso em: 09 Mar. 2018. BEVILÁQUA, Clóvis. Código Civil dos Estados Unidos do Brasil comentado. Rio de Janeiro - São Paulo: Francisco Alves. 1955.

BRASIL, Constituição (1988). Constituição da República Federativa do Brasil, 1988. Brasília: Senado Federal, 1988. 292 p. BRASIL. Conselho da Justiça Federal, Centro de Estudos Judiciários. Jornadas de direito civil I, III, IV e V : enunciados aprovados. Coordenador científico Ministro Ruy Rosado de Aguiar Júnior. Brasília, 2012. Disponível em: <http://www.jf.jus.br/cjf/CEJCoedi/jornadas-cej/enunciados-aprovados-da-i-iii-iv-e-v-jornada-de-direitocivil/compilacaoenunciadosaprovados1-3-4jornadadircivilnum.pdf>. Acesso em: 20 abr. 2018.

BRASIL. Lei no. 10.406 de 10 de janeiro de 2002. Institui o Código Civil. Diário Oficial da República Federativa do Brasil. Brasília, DF, 10 jan. 2002. Disponível em: <http://www.planalto.gov.br/ccivil_03/leis/2002//10406.htm> Acesso em: 15 mar. 2018.

BRASIL. Lei no. 11.924 de 17 de abril de 2009. Altera o art. 57 da Lei $n=6.015$, de 31 de dezembro de 1973, para autorizar o enteado ou a enteada a adotar o nome da família do padrasto ou da madrasta. Diário Oficial da República Federativa do Brasil. Brasília, DF, 17 abr. 2009. Disponível em:

<http://www.planalto.gov.br/ccivil_03/_Ato2007-2010/2009/Lei/L11924.htm> Acesso em: 30 mar. 2018.

BRASIL. Lei n‥ 6.015 de 31 de dezembro de 1973. Dispõe sobre os registros públicos, e dá outras providências. Diário Oficial da República Federativa do Brasil. Brasília, DF, 31 dez. 1973. Disponível em:

<http://www.planalto.gov.br/ccivil_03/leis/6015.htm> Acesso em: 30 mar. 2018. DIAS, Maria Berenice. Manual de Direito das Famílias. 2. ed. rev. Porto Alegre: Livraria do Advogado, 2005. 574 p.

BRASIL. Conselho da Justiça Federal. Disponível em: <http://daleth.cjf.jus.br>. Acesso em 20 set. 2017. 
. Constituição (1988). Constituição (da) República Federativa

do Brasil. Brasília: Senado Federal, 1988. Disponível em:

$<$ http://www.planalto.gov.br>. Acesso em 30 set. 2017.

. Lei №. 10.406, de 10 de Janeiro de 2002. Institui o Código Civil.

Disponível em: <http://www.planalto.gov.br>. Acesso em: 24 mar. 2018.

. Superior Tribunal de Justiça. Disponível em: <www.stj.jus.br>.

Acesso em 24 mar. 2018.

. Supremo Tribunal Federal. Disponível em: <www.stf.jus.br>.

Acesso em 24 mar. 2018.

DINIZ, M. H. Curso de Direito Civil brasileiro: Direito de Família. 23. ed. São

Paulo: Saraiva, 2008. v. 5. p. 9.

DINIZ, Maria Helena. Curso de Direito Civil Brasileiro: Direito de Família. v. 05.

27 ed. São Paulo: Editora Saraiva, 2012.

FACHIN, Luis Edson. Elementos críticos do direito de família. Rio de Janiero:

Renovar, 1999.

FARIAS, Cristiano Chaves de. Escritos de direito de família. Rio de Janeiro:

Lumen Juris, 2007.

FARIAS, Cristiano Chaves de; ROSENVALD, Nelson. Direito das Famílias. Rio de Janeiro: Editora Lumen Juris, 2008.

FARIAS, Cristiano Chaves de; ROSENVALD, Nelson. Curso de Direito Civil:

Famílias. 5. ed. rev., ampl. e atul. Salvador: Juspodivm, 2013. 1.094 p.

GAMA, Guilherme Calmon Nogueira da. Direito de família brasileiro. São Paulo: Ed. Juarez de Oliveira, 2007.

GOMES, O. Direito de Família. 11. ed. Rio de Janeiro: Forense, 1998. p. 35.

JUNIOR, Nelson Nery; NERY, Rosa Maria de Andrade. Código Civil Comentado. 8.

ed. . rev., ampl. e atul. São Paulo: Revista dos Tribunais, 2011. 1.758 p.

MADALENO, Rolf. Curso de Direito de Família. Rio de Janeiro: Forense, 2008.

MINAS GERAIS (ESTADO). Tribunal de Justiça do Estado de Minas Gerais.

Disponível em: <www.tjmg.jus.br>. Acesso em 24 set. 2016.

OLIVEIRA, José Sebastião. Fundamentos Constitucionais do Direito de Família. São

Paulo:RT, 2002.

PEREIRA, Caio Mario da Silva. Instituições de direito civil. Rio de Janeiro: Editora

Forense, 2006.

RODRIGUES, Silvio. Direito Civil. São Paulo: Saraiva, 2002, p. 321. v.6

RIO GRANDE DO SUL (ESTADO). Tribunal de Justiça do Estado do Rio

Grande do Sul. Disponível em: <http://www.tjrs.jus.br>. Acesso em 24 set. 2016.

SARMENTO, Daniel. Casamento e União entre Pessoas do mesmo Sexo:

Perspectivas Constitucionais in: Igualdade, Diferença e Direitos Humanos. Rio de Janeiro: Editora Lumen Juris, 2008.

TARTUCE, Flávio; SIMÃO, José Fernando. Direito Civil: Direito de Família. v. 5. 7 ed., rev., atual. e ampl. São Paulo: Editora Método, 2012.

STF reconhece dupla paternidade. Migalhas. Disponível em:

<http://www.migalhas.com.br>. Acesso em 24 jan. 2018. 
TEIXEIRA, Ana Carolina Brochado; RODRIGUES, Renata de Lima.

Multiparentalidade como efeito da socioafetividade nas famílias

recompostas. Revista Brasileira de Direito das Famílias e Sucessões, Porto

Alegre, v.11, n.10, p. 34-60, jun./jul. 2009.

WELTER, Belmiro Pedro. Teoria Tridimensional no Direito de Família:

Reconhecimento de todos os direitos das filiações genética e socioafetiva. Revista Brasileira de Direito das Famílias e Sucessões, Porto Alegre, v.8, n.8 , p. 104123, fev./mar. 2009

WELTER, Belmiro Pedro. Igualdade entre as filiações biológica e socioafetiva. São Paulo: Revista dos Tribunais, 2003. 